\title{
Fabrication of a Novel Ta(Zn)O Thin Film on Titanium by Magnetron Sputtering and Plasma Electrolytic Oxidation for Cell Biocompatibilities and Antibacterial Applications
}

\author{
Heng-Li Huang 1,2,+(D, Ming-Tzu Tsai ${ }^{3,+}$, Yin-Yu Chang ${ }^{4, *}$, Yi-Jyun Lin ${ }^{4}$ and Jui-Ting Hsu 1,2 \\ 1 School of Dentistry, China Medical University, Taichung 404, Taiwan; henleyh@gmail.com (H.-L.H.); \\ jthsu@mail.cmu.edu.tw (J.-T.H.) \\ 2 Department of Bioinformatics and Medical Engineering, Asia University, Taichung 413, Taiwan \\ 3 Department of Biomedical Engineering, Hungkuang University, Taichung 433, Taiwan; \\ anniemtt@sunrise.hk.edu.tw \\ 4 Department of Mechanical and Computer-Aided Engineering, National Formosa University, \\ Yunlin 632, Taiwan; xyz10920@yahoo.com.tw \\ * Correspondence: yinyu@gs.nfu.edu.tw; Tel.: +1-886-5-631-355 \\ + Equal contributors.
}

Received: 29 April 2020; Accepted: 16 May 2020; Published: 18 May 2020

\begin{abstract}
Pure titanium (Ti) and titanium alloys are widely used as artificial implant materials for biomedical applications. The excellent biocompatibility of Ti has been attributed to the presence of a natural or artificial surface layer of titanium dioxide. Zinc oxide and tantalum oxide thin films are recognized due to their outstanding antibacterial properties. In this study, high power impulse magnetron sputtering (HiPIMS) was used for the deposition of tantalum oxide and zinc-doped $\mathrm{Ta}(\mathrm{Zn}) \mathrm{O}$ thin films on Ti with rough and porous surface, which was pretreated by plasma electrolytic oxidation (PEO). Surface morphology, antibacterial property as well as cell biocompatibility were analyzed. The antibacterial effect was studied individually for the Gram-positive and Gram-negative bacteria Staphylococcus aureus (S. aureus) and Actinobacillus actinomycetemcomitans (A. actinomycetemcomitans). The deposited $\mathrm{Ta}(\mathrm{Zn}) \mathrm{O}$ coating was composed of amorphous tantalum oxide and crystalline $\mathrm{ZnO}$. The antibacterial results on the tantalum oxide and $\mathrm{Ta}(\mathrm{Zn}) \mathrm{O}$ coated Ti indicated a significant inhibition of both S. aureus and A. actinomycetemcomitans bacteria when compared with the uncoated Ti samples. The deposited $\mathrm{Ta}(\mathrm{Zn}) \mathrm{O}$ showed the best antibacterial performance. The $\mathrm{Ta}(\mathrm{Zn}) \mathrm{O}$ coated Ti showed lower level of the cell viability in MG-63 cells compared to other groups, indicating that Zn-doped $\mathrm{Ta}(\mathrm{Zn}) \mathrm{O}$ coatings may restrict the cell viability of hard tissue-derived MG-63 cells. However, the biocompatibility tests demonstrated that the tantalum oxide and $\mathrm{Ta}(\mathrm{Zn}) \mathrm{O}$ coatings improved cell attachment and cell growth in human skin fibroblasts. The cytotoxicity was found similar between the $\mathrm{Ta}_{2} \mathrm{O}_{5}$ and $\mathrm{Ta}(\mathrm{Zn}) \mathrm{O}$ coated Ti. By adopting a first PEO surface modification and a subsequent HiPIMS coating deposition, we synthetized amorphous tantalum oxide and $\mathrm{Ta}(\mathrm{Zn}) \mathrm{O}$ coatings that improved titanium surface properties and morphologies, making them a good surface treatment for titanium-based implants.
\end{abstract}

Keywords: high power impulse magnetron sputtering; zinc oxide; tantalum oxide; thin film; plasma electrolytic oxidation; antibacterial; biocompatibility

\section{Introduction}

With the growing demand for metal implants in the medical industry, surface treatment, which includes various types of bio-coating and different surface modification techniques used for fabrication 
of biomaterials, is widely applied in implants for enhancing the biocompatibility and antibacterial properties between metals and tissues. This method can improve the biocompatibility of the metal implant surface and preserve the mechanical properties of the implant body [1-3]. Although dental and orthopedic implants have improved their biomedical properties and enhanced the life of many patients, they are not free from the influence of bacteria. Pure titanium and its alloys are the most commonly used materials for permanent implants in contact with soft and hard tissues. Microbial infection is one of the main causes of implant failure. Most of these infections are caused by common bacteria, such as Staphylococcus aureus (S. aureus) and Actinobacillus actinomycetemocomitans (A. actinomycetemocomitans) which show enhanced activity on metallic and biocompatible surfaces used for implants $[4,5]$. Therefore, it is worth using surface treatments with two main categories: surface modification (physical, chemical or combined) and coatings (physical, chemical or combined).

Different surface modification methods are used to improve mechanical, tribological and biomedical properties of titanium include plasma nitriding, electrodeposition and anodizing, etc. Even though each treatment has its own unique advantage, plasma electrolytic oxidation (PEO) treatment, also called anodic spark oxidation or micro-arc oxidation, has become increasingly popular for titanium alloys owing to the excellent adhesion strength of the oxides on the surface and environmental friendliness [6]. This method produces a bioactive surface with a rough and porous structure at the surface of a work piece electrode immersed in an appropriate electrolyte by applying a high pulsed voltage [7]. For example, with respect to the PEO process, a bioactive $\mathrm{TiO}_{2}$ layer can be formed on the surface of Ti. In addition, many studies have been directed towards making the surfaces of implants as biocompatible and resistant against bacterial attachment as possible, particularly for titanium-based alloys which are often the materials of choice for dental and orthopedic implants. For example, titanium surfaces have been modified by photocatalytic titanium dioxide $\left(\mathrm{TiO}_{2}\right)$ coatings and alloying titanium with silver and copper or producing the $\mathrm{TiO}_{2}$ surface layer with silver or zinc $[8,9]$. Tantalum (Ta) is a transition element with substantial chemical inertness under room temperature $[10,11]$. Ta is also a biocompatible metal and can induce osseointegration between bone tissue and it surface [12]. In clinics, porous Ta implants have been used widely in orthopedics and dentistry owing to their excellent biocompatibilities [13-15]. For tantalum oxide materials, our pervious study [16] also revealed that $\mathrm{Ta}_{2} \mathrm{O}_{5}$ films are antibacterial and possess considerable biocompatibility with fibroblast cells. Furthermore, $\mathrm{Ta}_{2} \mathrm{O}_{5}$ films are more resistant to corrosion than $\mathrm{TiO}_{2}$ films [17]. Besides, zinc $(\mathrm{Zn})$ is an essential microelement involved with the different types of metabolism in the human body [18]. An appropriate amount of $\mathrm{Zn}$ can improve the integration of bone protein, stimulate osteoblast differentiation, and further increase the proliferation of bone cells [19]. Concerning the positive correlation between alkaline phosphatase (ALP) and osteoblast differentiation, a previous research by Yamaguchi et al. [20] indicated that a boost in ALP signal takes place when $\mathrm{Zn}$ is added to a human bone. The research conducted by Jin et al. [21] demonstrated that after implanting Zn into the surface of $\mathrm{Ti}$, the antibacterial property was increased. $\mathrm{ZnO}$ was revealed to have antibacterial property against Staphylococcus aureus and Escherichia coli [22-24]. A duplex treatment combining PEO and physical vapor deposition (PVD) has been reported as enhancing mechanical properties and antibacterial performance [25]. The study proved that the Ag-contained $\mathrm{TiO}_{2}$ coatings synthesized by combining PEO and magnetron sputtering possessed improved antibacterial activities without cytotoxic effect. Huang et al. also showed that the duplex treatment consisting of PEO and PVD could synthesize porous $\mathrm{Ta}_{2} \mathrm{O}_{5}$ films to have good biocompatibility [26].

Taking into account all of the above, the combination of modified $\mathrm{Ta}_{2} \mathrm{O}_{5}$ films possessing bactericidal effects with rough and porous Ti surfaces that inhibit bacterial adhesion and keep cell viability can be a promising strategy in order to create a synergic interaction that enhances the antibacterial properties and cell biocompatibilities of the final coating. The purpose of this study is to synthesize zinc-doped $\mathrm{Ta}(\mathrm{Zn}) \mathrm{O}$ films to form a bioactive and antibacterial surface which maybe more helpful for the possibility of clinical applications. Among the PVD technologies, HiPIMS is a comparatively new magnetron sputtering technique that provides a higher plasma ionization ability 
for the deposition of higher quality coatings with dense microstructure. Reactive-HiPIMS technique utilizes the magnetron sputtering in a reactive gas environment. It brings possibilities to enhance and tailor coating properties and often possesses better adhesion to the substrate, especially for those of oxide coatings, such as photoactive and antibacterial copper oxides and $\mathrm{TiO}_{2}$.

This study applied plasma electrolytic oxidation (PEO) to pure Ti specimens to form rough and porous $\mathrm{TiO}_{2}$ surfaces for biocompatible purpose and further used HiPIMS in a reactive environment with oxygen to deposit zinc-doped $\mathrm{Ta}(\mathrm{Zn}) \mathrm{O}$ films onto the surface of the PEO-treated Ti. This study investigated the antibacterial property of the coating against Gram-positive and Gram-negative bacteria. ISO 10993-5 cytotoxicity analyses were performed in soft and hard tissues, and MTT assays were applied to assess the cell survival rate.

\section{Materials and Methods}

\subsection{Sample Preparation}

Pure Ti samples (ASTM B265 Grade 2) were used as the experimental starting material. In order to remove the surface containment, the Ti samples were ground using abrasive papers and polished with colloidal alumina suspension to obtain the surface roughness Ra $0.5 \mu \mathrm{m}$, and then the samples were rinsed ultrasonically in alcohol solution for $15 \mathrm{~min}$ and dried in hot air. Sand blasting of the pure Ti was then conducted to obtain high adhesion strength for the following PEO treatment and deposition of tantalum oxide and $\mathrm{Ta}(\mathrm{Zn}) \mathrm{O}$ films. Figure 1 shows the illustration of the technical processing route of the samples. After sand blasting, all the Ti samples were ultrasonically cleaned with a successive ethyl alcohol, and distilled water; and then air-dried. PEO was used to produce rough and porous oxide films on the Ti surfaces. An alternating bipolar pulse power source was used to fabricate the oxide films. The pulse parameters including voltage, current, frequency, and duty cycle can be adjusted independently. In this study, the PEO was operated using a pulsed electrical signal $(500 \mathrm{~Hz}$, $+280 \mathrm{~V} /-15 \mathrm{~V}$ and $50 \%$ duty cycle) and a current density limit of $120 \mathrm{~mA} / \mathrm{cm}^{2}$. The Ti sample was set as an anode, and a flat stainless steel was used as the cathode. A mixed aqueous solution containing $0.15 \mathrm{M}$ $\mathrm{Ca}\left(\mathrm{CH}_{3} \mathrm{COO}\right)_{2} \cdot \mathrm{H}_{2} \mathrm{O}$ and $0.02 \mathrm{M} \mathrm{C}_{3} \mathrm{H}_{7} \mathrm{CaO}_{6} \mathrm{P} \cdot \mathrm{H}_{2} \mathrm{O}$ was used as the electrolyte. The PEO procedure was conducted for $90 \mathrm{~s}$. The electrolyte was cooled by a cooling system to keep its temperature below $50{ }^{\circ} \mathrm{C}$. After PEO treatment, the samples were taken out of electrolyte, ultrasonically cleaned in ethyl alcohol and air-dried before performing the following deposition of tantalum oxide and $\mathrm{Ta}(\mathrm{Zn}) \mathrm{O}$ films.

Tantalum oxide and $\mathrm{Ta}(\mathrm{Zn}) \mathrm{O}$ films were deposited on the PEO pretreated Ti by using HiPIMS with high-purity Ta and $\mathrm{Zn}$ targets $(99.99$ at. $\%$, dia. $=7.5 \mathrm{~mm}$ ). A pulsed power generator (TruPlasma Highpulse Series 4000, TRUMPF Hüttinger GmbH Co., Ditzingen, Germany) was connected to the targets. The Ti samples were placed on a substrate holder for the deposition, and the distance between the target and Ti substrates was $60 \mathrm{~mm}$. A base pressure prior to deposition was less than $1.3 \times 10^{-3} \mathrm{~Pa}$. Before deposition, the substrates were ion etched for $20 \mathrm{~min}$ at a substrate bias potential of $-800 \mathrm{~V}$ in argon (Ar) plasma. To enhance film adhesion, Ta ion bombardment using bias voltage of $-800 \mathrm{~V}$ was applied before the deposition. For the deposition of tantalum oxide and $\mathrm{Ta}(\mathrm{Zn}) \mathrm{O}$ films, the flow rate of Ar was set at $50 \mathrm{sccm}$ and oxygen $\left(\mathrm{O}_{2}\right)$ was introduced through a separate mass flow controller to maintain a deposition pressure of $0.4 \mathrm{~Pa}$ for the reactive sputtering deposition. In this study, a unipolar mode was used with a fixed pulse on-time of $20 \mu \mathrm{s}$, frequency of $500 \mathrm{~Hz}$ and duty cycle of $5 \%$. A bias voltage of $-60 \mathrm{~V}$ in the negative periods was connected to the Ti substrates during deposition. $\mathrm{The} \mathrm{Ta}(\mathrm{Zn}) \mathrm{O}$ films were deposited with the cathode powers of the Ta target and $\mathrm{Zn}$ target set to 500 and $200 \mathrm{~W}$, respectively. All the deposition experiments were performed without additional heating, and the substrate temperature was all below $80^{\circ} \mathrm{C}$. The total thickness of the coatings was controlled to $0.2 \sim 0.3 \mu \mathrm{m}$ by using a deposition time of $15 \mathrm{~min}$. 


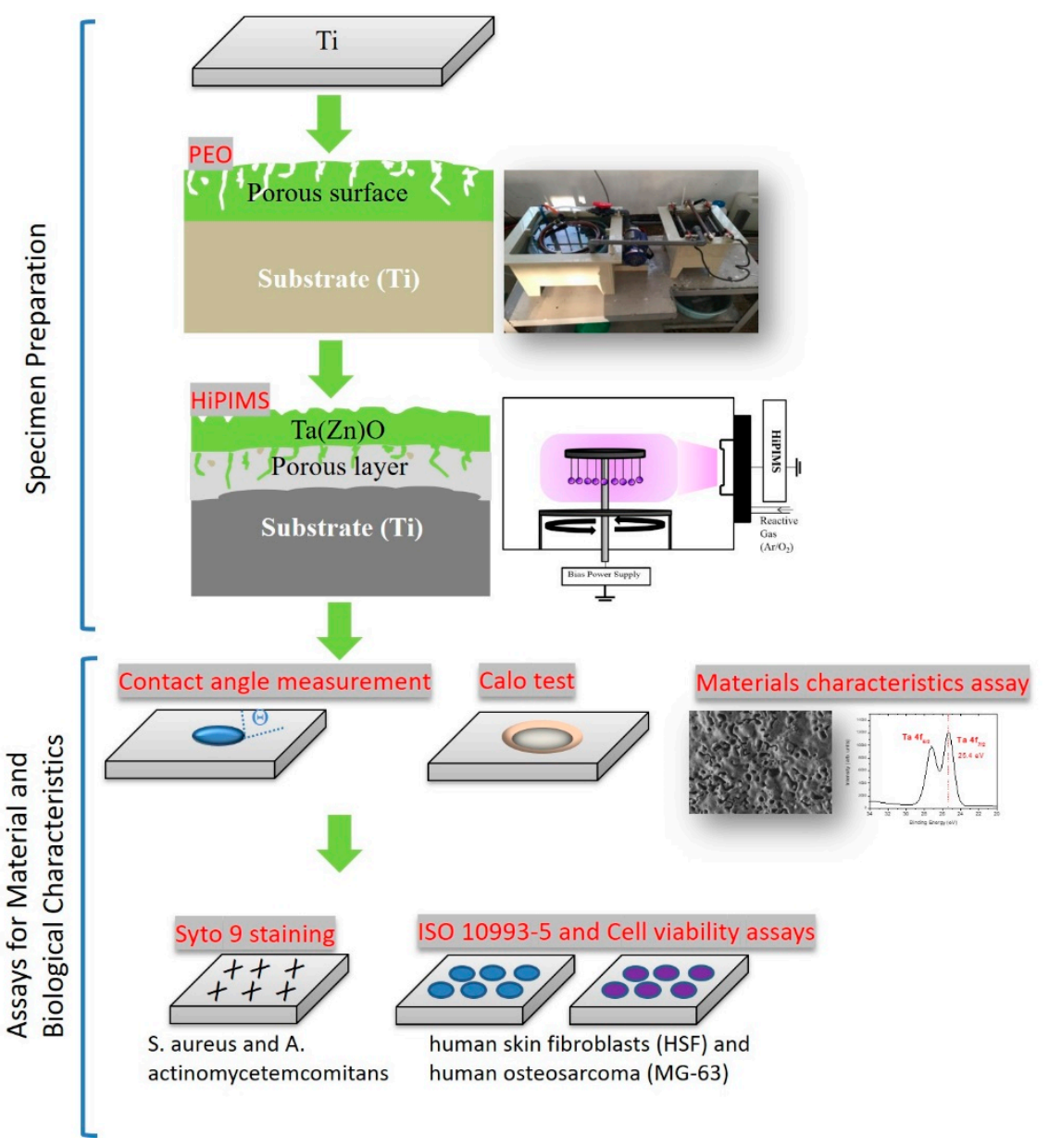

Figure 1. Schematic illustration of the technical processing route.

\subsection{Materials Characteristics Measurement}

The surface morphology and chemical composition of the coated samples were investigated by using a JSM-6700F field emission scanning electron microscope (FESEM, JEOL Inc., Tokyo, Japan), which equipped with an energy-dispersive x-ray spectroscopy (EDS) system. Optical microscope instruments are preferred for the evaluation of surface morphology of soft Ti implant materials. An accurate measure of both the magnitude and complexity of the surface extensions beyond the mean plane is necessary. In this study, the surface morphology and surface roughness were examined with a 3D laser scanning microscope (VK-X100, Keyence Inc., Osaka, Japan). A typical surface roughness $\mathrm{Ra}$ value, which showed the arithmetic mean value of the surface differences from the surface, was measured. In addition, the point height of irregularities $\mathrm{Rz}$, which showed the average value of the absolute heights of five highest profile peaks and the depths of five deepest valleys within the evaluated length, was measured. An X-ray photoelectron spectroscope (PHI1600 XPS, Physical Electronics Inc., Chanhassen, MN, USA) with non-monochromatized $\mathrm{Mg} \mathrm{K} \alpha$ radiation was used to identify the chemical binding of the tantalum oxide and zinc-doped $\mathrm{Ta}(\mathrm{Zn}) \mathrm{O}$ coatings. The sample surface was cleaned for $60 \mathrm{~s}$ using an Ar-ion gun to eliminate the influence of the surface contamination as much as possible before the spectrum was collected. Energy calibration was conducted by reference to the $\mathrm{Au} 4 \mathrm{f}_{7 / 2}$ peak at $83.8 \mathrm{eV}$ from a clean gold surface. The spectral ranges at $26 \pm 12 \mathrm{eV}, 1035 \pm 20 \mathrm{eV}$ and $531 \pm 10 \mathrm{eV}$, corresponded to the binding energies of Ta4f, Zn2p and O1s, respectively. X-ray diffraction (XRD) patterns were obtained with a D8 series X-ray diffractometer (Bruker Taiwan Co., Ltd., New Taipei City, Taiwan) using the CuK $\alpha$ radiations $(\lambda=1.54059 \AA)$ in the $2 \theta$ range between $20^{\circ}$ and $80^{\circ}$ with a scanning step size of $0.02^{\circ}$. It was performed at a low glancing incidence angle of $2^{\circ}$ 
allowing identifying the coating structure. A Calo test, also known as a ball cratering test, was used to measure the thickness of the deposited coatings. The Calo tester consisted of a holder for the coated surface to be tested and a steel ball that was rotated against the measured surface by a rotating shaft. An optical microscope was used to take measurements of the crater diameter, and the coating thickness was calculated and obtained.

\subsection{Contact Angle Measurement}

After each coating sample was washed for $30 \mathrm{~min}$ alternately into containers with ethanol and deionized water in an ultrasonic cleaner, samples were dried in a clean and dry oven at $55{ }^{\circ} \mathrm{C}$ for $6 \mathrm{~h}$. Then deionized water dropped from a micrometric syringe and touched onto the surface of untreated $\mathrm{Ti}$ (control), $\mathrm{Ta}_{2} \mathrm{O}_{5}$ and $\mathrm{Ta}(\mathrm{Zn}) \mathrm{O}$ coated samples. The status of the water on the samples was photographed by an optical instrument to measure the static contact angles of water on all samples by the measurement device (FTA-125, First Ten Angstroms, Portsmouth, VA, USA) at room temperature. Each contact angle reported here is the mean of at least 5 independent measurements [26].

\subsection{Antibacterial Analyses}

Five hundred $\mu \mathrm{L}$ of bacterial liquid suspensions $\left(2 \times 10^{7} \mathrm{cfu} / \mathrm{mL}\right)$ including the Gram-positive bacterium Staphylococcus aureus (S. aureus) and the Gram-negative bacterium of Actinobacillus actinomycetemocomitans (A. actinomycetemocomitans) were individually dripped on the surfaces of all the samples. After incubation under a relative humidity of $96 \%$ at $37{ }^{\circ} \mathrm{C}$ for $4 \mathrm{~h}$ in a dark environment, the surfaces of all samples were rinsed three times with phosphate-buffered saline (PBS). The retained bacteria were then fixed with $4 \%$ paraformaldehyde (Sigma-Aldrich, St. Louis, MO, USA) for $15 \mathrm{~min}$. Then all the samples were stained with $10 \mu \mathrm{M}$ SYTO 9, which is a green fluorescent nucleic acid used to stain live and dead bacteria, for $30 \mathrm{~min}$ at room temperature. By using an enzyme-linked immunosorbent assay reader (Synergy HT, BioTek Instruments, Winooski, VT, USA), the adhered bacteria on the samples were quantified by measuring the fluorescence at $488 \mathrm{~nm}$.

\subsection{Biocompatibility Tests of Cytotoxicity and Cell Viability}

To evaluate the biocompatible characteristics of all the samples with specific element compositions, the cytotoxicity test based on ISO 10993-5 assay and cell viability study were performed by using two cell lines, human skin fibroblasts (HSF) and human osteosarcoma (MG-63). HSF (product No. BCRC 60153) and MG-63 (product No. BCRC 60279) cells were purchased from Bioresource Collection and Research Center (Hsinchu City, Taiwan). According to the procedure of cytotoxicity test suggested from the standard of ISO 10993-5, each kind of the samples, such as the the regular culture medium (DMEM), uncoated $\mathrm{Ti}$ (control), specimens with $\mathrm{Ta}_{2} \mathrm{O}_{5}$ and $\mathrm{Ta}(\mathrm{Zn}) \mathrm{O}$ thin films, was individually immersed into serum-free medium with gently shaking at $4{ }^{\circ} \mathrm{C}$. After $72 \mathrm{~h}$, the conditioned medium of each kind of samples was collected by passing through the $0.22 \mu \mathrm{m}$ sterile filter for the ISO 10993-5 assay. HSF or MG-63 cells cultured in plates with Dulbecco's Modified Eagle Medium (DMEM, Gibco, Carlsbad, CA, USA) were incubated at $37^{\circ} \mathrm{C}$ in $5 \% \mathrm{CO}_{2}$ overnight, and then replaced with the conditioned medium above for further 24-h culture. Then a 3-(4,5-dimethylthiazol-2-yl)-2,5-diphenyltetrazolium bromide (MTT assay) was performed. MTT, which is one method to detect the activity of mitochondria in live cells, shows the cell viability. All cells were washed twice by Dulbecco's phosphate-buffered saline (DPBS) and cultured for another $4 \mathrm{~h}$ with MTT-contained medium at $37{ }^{\circ} \mathrm{C}$ with $5 \% \mathrm{CO}_{2}$. The intracellular purple formazon in live cells was eluted by DMSO (Sigma), quantified by using the ELISA reader (Molecular Devices, San Jose, CA, USA) at the absorbance of $570 \mathrm{~nm}$ with SoftMax Pro software (Molecular Devices, San Jose, CA, USA). The measuring procedure was performed and protected from the light.

To examine the effect of all the samples prepared in this study on the cell viability, HSF and MG-63 cells were also cultured directly onto the surface of the uncoated $\mathrm{Ti}^{\mathrm{i}}, \mathrm{Ta}_{2} \mathrm{O}_{5}$ and $\mathrm{Ta}(\mathrm{Zn}) \mathrm{O}$ films and incubated at $37^{\circ} \mathrm{C}$ in $5 \% \mathrm{CO}_{2}$ for $48 \mathrm{~h}$. All cells were then washed twice by Dulbecco's 
phosphate-buffered saline (DPBS) and cultured for another $4 \mathrm{~h}$ with MTT-contained medium at $37^{\circ} \mathrm{C}$ with $5 \% \mathrm{CO}_{2}$. The intracellular purple formazon in live cells was eluted by DMSO (Sigma), quantified by using the ELISA reader (Molecular Devices, San Jose, CA, USA) at the absorbance of $570 \mathrm{~nm}$ with SoftMax Pro software (Molecular Devices, San Jose, CA, USA). The measuring procedure was performed and protected from the light.

\subsection{Statistical Analyses}

The ANOVA analysis tool of variance was used to perform the statistical analyses of the contact angle, antibacterial analyses, cytotoxicity and cell viability of all samples. Post hoc pairwise comparisons were conducted precisely using the Turkey method. Each experiment was independently performed and duplicated and the differences were considered significant at the $p<0.05$ level. SPSS v19 (IBM Corporation, Armonk, NY, USA) was used for statistical analyses.

\section{Results and Discussion}

\subsection{Microstructure and Surface Morphology Analyses}

In this study, a field-emission scanning electron microscope and a 3D laser scanning microscope were used to observe the surface morphology of the specimens treated by PEO and HiPIMS, as shown in Figure 2. When a pulsed DC was applied on the uncoated Ti during the PEO treatment, a porous oxide layer was formed, and the surfaces revealed numerous micron-sized pores. The SEM images revealed that the prepared tantalum oxide and $\mathrm{Ta}(\mathrm{Zn}) \mathrm{O}$ films fully cover the porous $\mathrm{TiO}_{2}$ surface generated by PEO. Followed by the oxide deposition by HiPIMS, the PEO-pretreated samples were still coated with tantalum oxide and $\mathrm{Ta}(\mathrm{Zn}) \mathrm{O}$, and still retained their porous structure. G. Greczynski et. al. [27] showed that in reactive processes of HiPIMS, metal reactivity, which controlled the rate of compound formation at the target, was expected to be a decisive parameter, as it affected the target sputtering condition and the extent of gas rarefaction. It was found that the film deposited using HiPIMS at low substrate temperature below $80^{\circ} \mathrm{C}$ allowed the sputtered particles to gain an optimal energy and form a compact layer on the surface of the substrate [28]. EDS was employed to measure the elemental composition of the oxide films. The chemical composition of the deposited tantalum oxide films comprised $21.7 \pm 1.8$ at. $\%$ of Ta and $78.3 \pm 2.1$ at. $\%$ of $\mathrm{O}$, which implied the formation of stoichiometric tantalum pentoxide $\left(\mathrm{Ta}_{2} \mathrm{O}_{5}\right)$ contained a higher fraction of oxygen, and indicated the presence of surface oxides on the surface [26]. The chemical composition of the deposited $\mathrm{Ta}(\mathrm{Zn}) \mathrm{O}$ films comprised $20.8 \pm 2.3$ at. $\%$ of Ta, $4.4 \pm 1.3$ at. $\%$ of $\mathrm{Zn}$, and $74.8 \pm 2.7$ at. $\%$ of $\mathrm{O}$. It showed that the $\mathrm{Ta}(\mathrm{Zn}) \mathrm{O}$ films deposited from Ta and $\mathrm{Zn}$ targets had small content of $\mathrm{Zn}(4.4 \pm 1.3$ at.\%). Philip D. Racka et. al. [29] had revealed that the condition of small fraction of zinc in the films was as a result of the preferential resputtering of $\mathrm{Zn}$ versus Ta.

3D Laser microscopy was adopted to examine the surface roughness of the specimens. The surface roughness Ra of the untreated Ti was $0.6 \pm 0.15 \mu \mathrm{m}$. After the PEO treatment and HiPIMS deposition, the $\mathrm{Ta}_{2} \mathrm{O}_{5}$ deposited Ti had higher surface roughness (mean roughness $\mathrm{Ra}=2.95 \pm 0.8 \mu \mathrm{m}$; point height of irregularities $\mathrm{Rz}=25.3 \pm 2.3 \mu \mathrm{m})$. The $\mathrm{Ta}(\mathrm{Zn}) \mathrm{O}$ deposited Ti also had higher surface roughness (mean roughness $\mathrm{Ra}=3.4 \pm 1.1 \mu \mathrm{m}$; point height of irregularities $\mathrm{Rz}=30.2 \pm 2.7 \mu \mathrm{m}$ ). This surface roughening and porous structure may improve in vivo biocompatibility, bone integration, and implant stability [30]. Low-energy metal-ion irradiation of the growing $\mathrm{Ta}_{2} \mathrm{O}_{5}$ and $\mathrm{Ta}(\mathrm{Zn}) \mathrm{O}$ films during HiPIMS has been shown to provide microstructure densification, without introducing incomplete surface diffusion developed during the deposition of DC magnetron sputtering [31,32]. The results verified that the $\mathrm{Ta}_{2} \mathrm{O}_{5}$ and $\mathrm{Ta}(\mathrm{Zn}) \mathrm{O}$ coated samples, which had undergone PEO, retained their porous surfaces with high surface roughness. Measured by the Calo test, the coating consisted of $\sim 6.5 \mu \mathrm{m}$ thick PEO-treated oxide layer and $0.2 \sim 0.3 \mu \mathrm{m}$ thick $\mathrm{Ta}_{2} \mathrm{O}_{5}$ and $\mathrm{Ta}(\mathrm{Zn}) \mathrm{O}$ coating layer which was prepared by HiPIMS for $15 \mathrm{~min}$. 
(a) $\mathrm{Ta}_{2} \mathrm{O}_{5}$
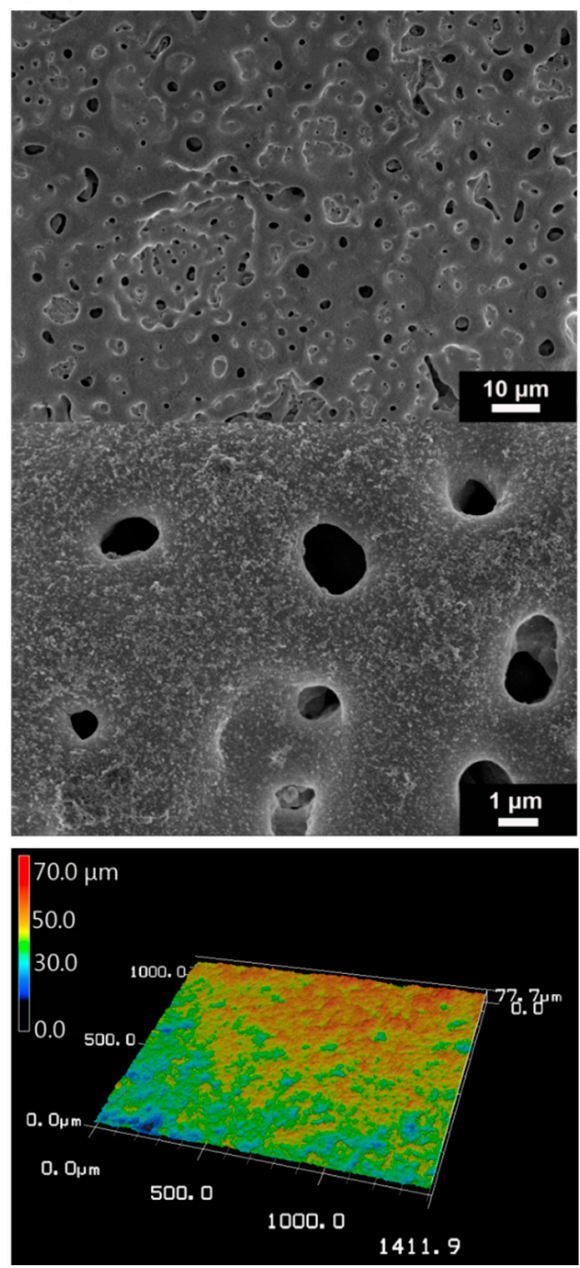

(b) $\mathrm{Ta}(\mathrm{Zn}) \mathrm{O}$
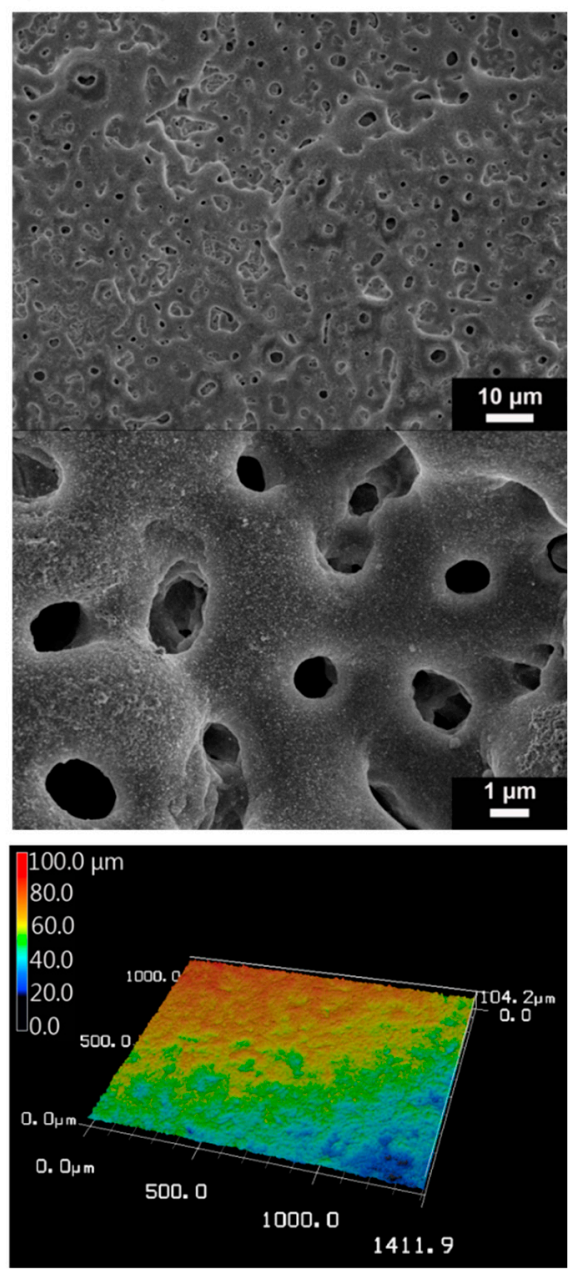

Figure 2. SEM images and $3 \mathrm{D}$ surface morphologies of the (a) $\mathrm{Ta}_{2} \mathrm{O}_{5}$ and $(\mathbf{b}) \mathrm{Ta}(\mathrm{Zn}) \mathrm{O}$ coated titanium samples.

Surface properties of thin films including hydrophilicity and hydrophobicity are explored to improve materials response in biological environments. Surface bio-functionalization routes based on vacuum deposition techniques, together with advances in surface engineering of biomaterials, are important [33]. A hydrophobic surface is likely to lower biocompatibility, whereas a highly hydrophilic surface promotes cell adhesion, migration, and growth. Accordingly, the wettability of the interface between fluid and medical implants should be balanced because the morphology and film composition affect wettability and hydrophobicity. The water contact angles of the untreated $\mathrm{Ti}_{1} \mathrm{Ta}_{2} \mathrm{O}_{5}$, and $\mathrm{Ta}(\mathrm{Zn}) \mathrm{O}$ coated samples were shown in Figure 3. Each point in the figure is an average value of at least ten measurements. The results demonstrated that the pure Ti substrate, $\mathrm{Ta}_{2} \mathrm{O}_{5}$, and $\mathrm{Ta}(\mathrm{Zn}) \mathrm{O}$ specimen had contact angles of $43.13 \pm 10.0^{\circ}, 3.3 \pm 0.36^{\circ}$, and $16.75 \pm 3.7^{\circ}$, respectively. It showed obviously that the $\mathrm{Ta}_{2} \mathrm{O}_{5}$ film on rough and porous $\mathrm{Ti}$ was capable of enhancing surface wettability, and adding $\mathrm{Zn}$ to thin films increased surface hydrophobicity as compared to $\mathrm{Ta}_{2} \mathrm{O}_{5}$. Nevertheless, the wettability of $\mathrm{Ta}(\mathrm{Zn}) \mathrm{O}$ was higher than that of the untreated $\mathrm{Ti}$ specimen. The hydrophilicity of $\mathrm{Ti}$ substantially improved after pretreatment with $\mathrm{PEO}$ and coating with $\mathrm{Ta}_{2} \mathrm{O}_{5}$ and $\mathrm{Ta}(\mathrm{Zn}) \mathrm{O}$. Surface chemistry and topography separately or together play important roles in the cell response to the oxidized Ti. Surface roughening and hydrophilicity may improve in vivo cell integration and implant stability [34]. 


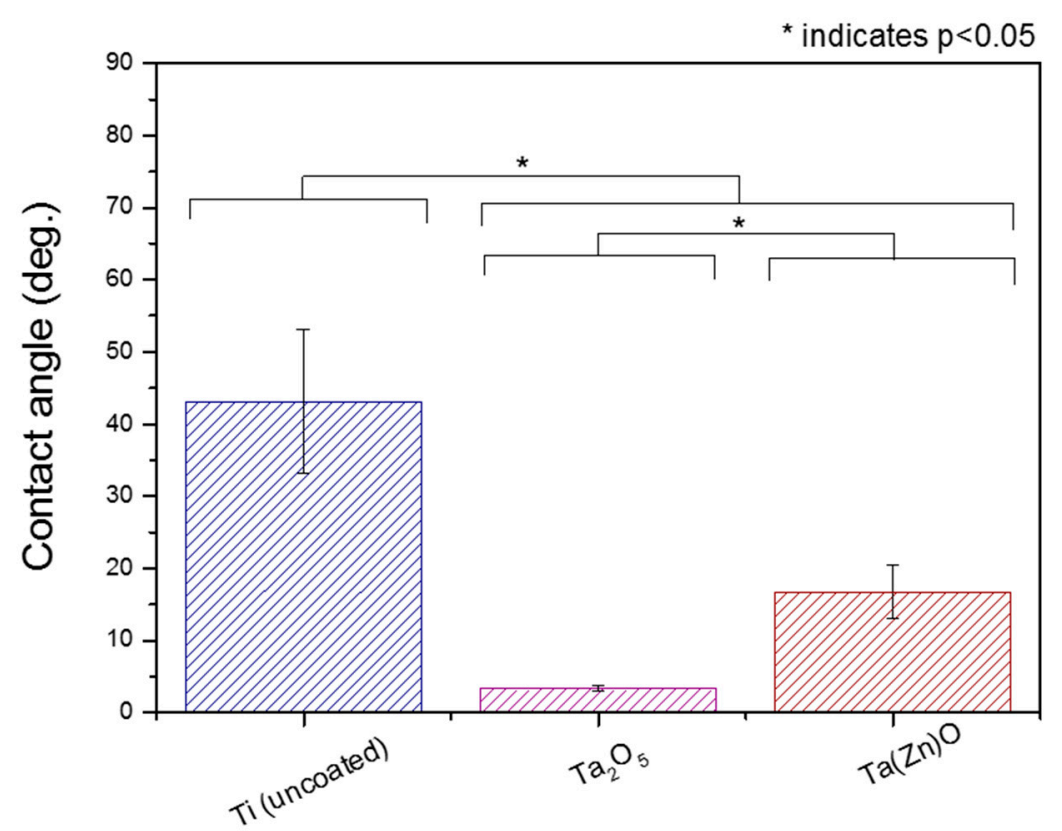

Figure 3. Contact angles of the uncoated $\mathrm{Ti}$, and $\mathrm{Ta}_{2} \mathrm{O}_{5}$ and $\mathrm{TaZnO}$ coated titanium samples. The mean vales of contact angles were different significantly among the untreated $\mathrm{Ti}$, and $\mathrm{Ta}_{2} \mathrm{O}_{5}$ and $\mathrm{Ta}(\mathrm{Zn}) \mathrm{O}$ coated titanium samples $(p<0.05)$. Post-hoc pairwise comparisons were conducted by the Turkey test. The differences were considered significant when $p<0.05$.

In order to investigate the oxidation states of elements present in $\mathrm{Ta}_{2} \mathrm{O}_{5}$ and $\mathrm{Ta}(\mathrm{Zn}) \mathrm{O}, \mathrm{XPS}$ was carried out and the results were shown in Figure 4. The chemical bonds of the $\mathrm{Ta}_{2} \mathrm{O}_{5}$ and $\mathrm{Ta}(\mathrm{Zn}) \mathrm{O}$ coatings were measured and identified. As shown in Figure $4 \mathrm{a}$, the XPS results of $\mathrm{Ta}_{2} \mathrm{O}_{5}$ coated Ti showed that $\mathrm{Ta}_{2} \mathrm{O}_{5}$ were deposited on PEO treated $\mathrm{Ti}$, and the shape and position of the XPS peaks (binding energies) clearly indicated the formation of tantalum oxide thin films on Ti [26]. The doublet at 25.7 27.5 eV confirmed the Ta oxidation state $\left(\mathrm{Ta}_{2} \mathrm{O}_{5}\right)[35,36]$. The results of XPS spectra of the $\mathrm{Ta}(\mathrm{Zn}) \mathrm{O}$ samples, as shown in Figure $4 \mathrm{~b}$, are similar to the $\mathrm{Ta}_{2} \mathrm{O}_{5}$ in addition to the presence of $\mathrm{Zn} 2 \mathrm{p}$ spectra. The chemical composition of the deposited $\mathrm{Ta}(\mathrm{Zn}) \mathrm{O}$ films measured by XPS consisted of $19.7 \pm 1.9$ at.\% of $\mathrm{Ta}, 5.3 \pm 1.5$ at. $\%$ of $\mathrm{Zn}$, and $75.0 \pm 3.8$ at.\% of $\mathrm{O}$. The results were similar to EDS. Figure $4 \mathrm{~b}$ shows the Ta4f, Zn2p and O1s core level XPS spectra of the Ta(Zn)O samples. Zn 2P peaks had the positions located at 1021.7 and $1044.7 \mathrm{eV}$ for the $\mathrm{Ta}(\mathrm{Zn}) \mathrm{O}$ thin films, corresponding to the chemical state of $\mathrm{Zn}$ $2 \mathrm{p}_{3 / 2}$ and $2 \mathrm{p}_{1 / 2}$ in $\mathrm{ZnO}$ [37]. The highly intense broad bands of oxygen confirmed the presence of $\mathrm{Zn}-\mathrm{O}$ and Ta-O bonds. It confirmed the formation of $\mathrm{ZnO}$ and $\mathrm{Ta}_{2} \mathrm{O}_{5}$ composite structure, and verified that $\mathrm{Zn}$ was successfully incorporated into $\mathrm{Ta}_{2} \mathrm{O}_{5}$ to form $\mathrm{Ta}(\mathrm{Zn}) \mathrm{O}$ using HiPIMS. 

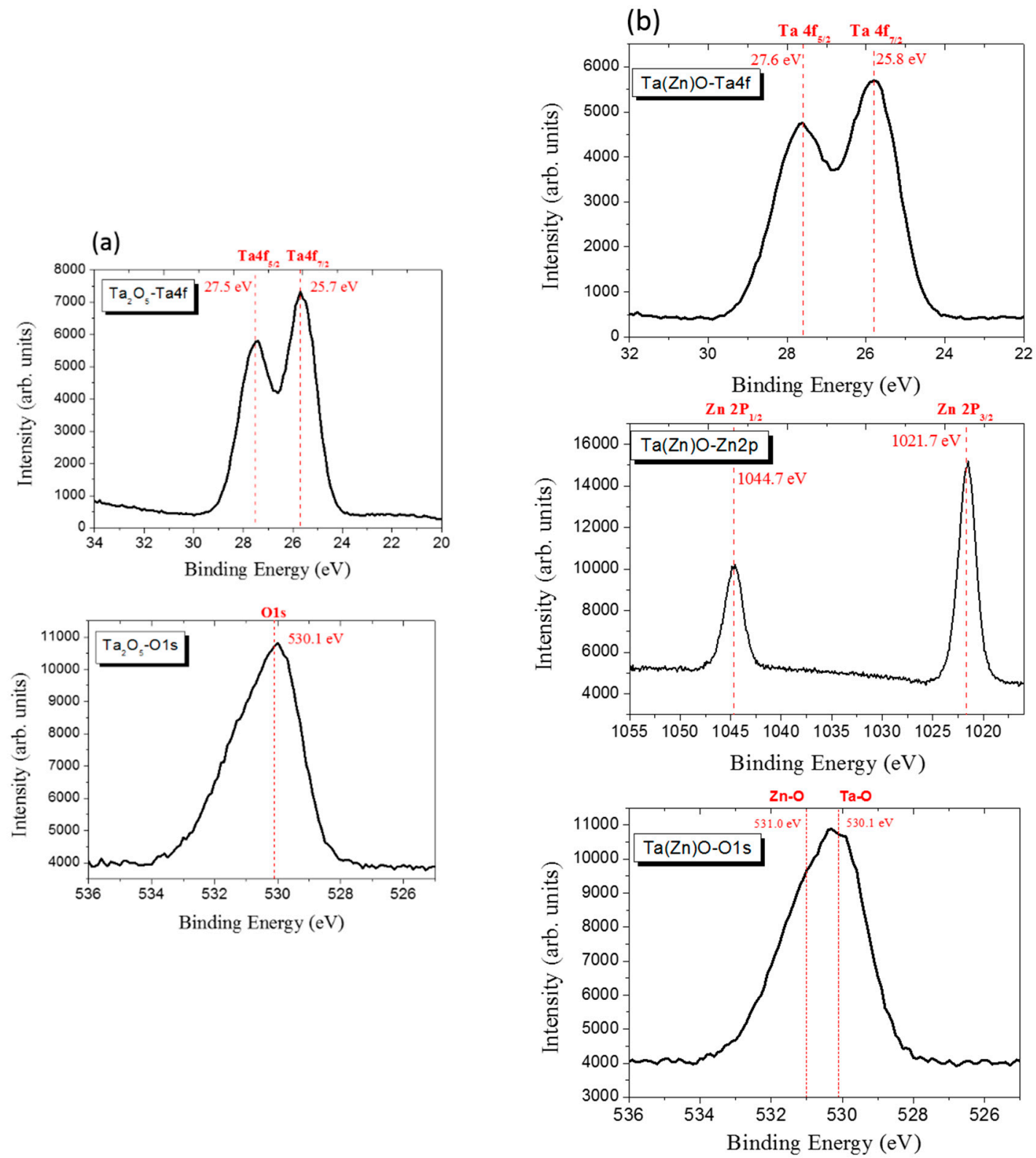

Figure 4. The Ta4f, $\mathrm{Zn} 2 \mathrm{p}$ and $\mathrm{O} 1$ s core level XPS spectra of the (a) $\mathrm{Ta}_{2} \mathrm{O}_{5}$ and (b) $\mathrm{Ta}(\mathrm{Zn}) \mathrm{O}$ thin film on Ti.

An X-ray diffractometer was used to analyze the crystallinity of the $\mathrm{Ta}_{2} \mathrm{O}_{5}$ and $\mathrm{Ta}(\mathrm{Zn}) \mathrm{O}$ thin films. Only the characteristic peaks of the $\mathrm{TiO}_{2}$ layer were observed for the $\mathrm{Ta}_{2} \mathrm{O}_{5}$ specimen (Figure 5). It showed that the $\mathrm{Ta}_{2} \mathrm{O}_{5}$ sample exhibited characteristic peaks of anatase and rutile $\mathrm{TiO}_{2}$ crystalline phases. The PEO-pretreated $\mathrm{Ta}_{2} \mathrm{O}_{5}$ sample showed characteristic peaks of $\mathrm{TiO}_{2}$ but not crystalline $\mathrm{Ta}_{2} \mathrm{O}_{5}$. The crystalline anatase and rutile $\mathrm{TiO}_{2}$ were formed by PEO treatment. The Ta(Zn)O films had characteristic peaks of the $\mathrm{TiO}_{2}$ layer, which was formed by $\mathrm{PEO}$, and the $\mathrm{ZnO}$ crystal phases. It indicated that the deposited $\mathrm{Ta}(\mathrm{Zn}) \mathrm{O}$ contained amorphous $\mathrm{Ta}_{2} \mathrm{O}_{5}$ and crystalline $\mathrm{ZnO}$. The development of the crystalline $\mathrm{ZnO}$ structure during growth was controlled by the HiPIMS deposition process [38,39]. 

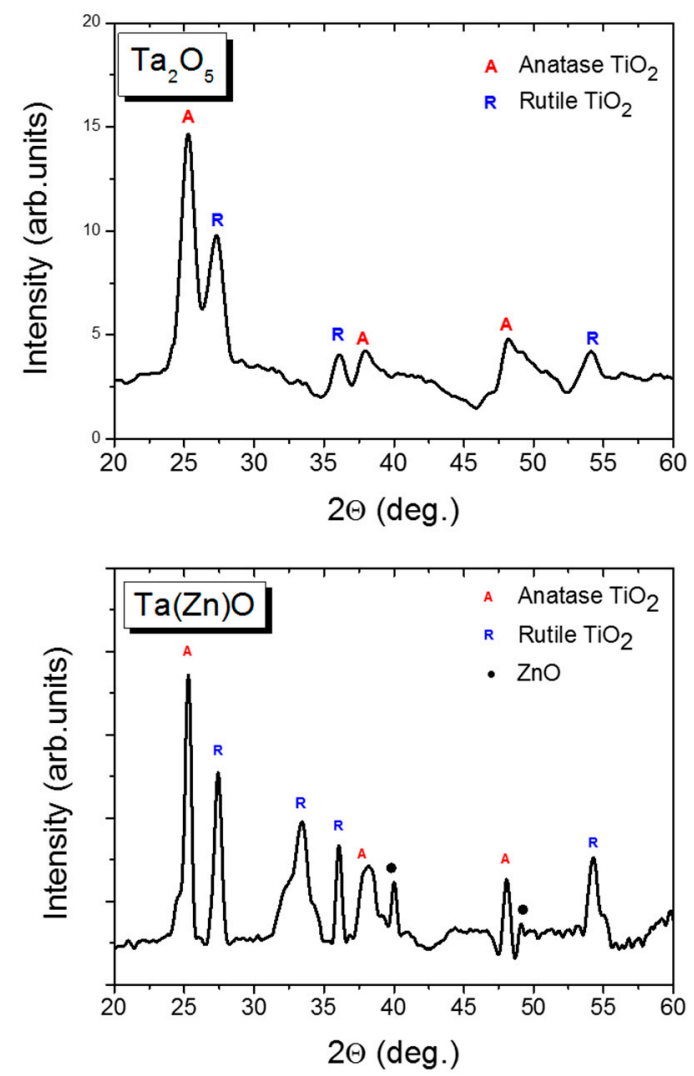

Figure 5. X-Ray diffraction spectra of the $\mathrm{Ta}_{2} \mathrm{O}_{5}$ and $\mathrm{Ta}(\mathrm{Zn}) \mathrm{O}$ coated Ti with PEO surface pretreatment.

\subsection{Antibacterial Properties}

SYTO 9 stain was applied to examine the antibacterial property of the untreated $\mathrm{Ti}, \mathrm{Ta}_{2} \mathrm{O}_{5}$, and $\mathrm{Ta}(\mathrm{Zn}) \mathrm{O}$ specimens against $S$. aureus and A. actinomycetemcomitans. In Figure 6, the relative fluorescence intensity represents the bacterial residue with STYO 9 stain. Lower relative fluorescence intensity indicates the potential and better capability of the antibacterial ability. $\mathrm{The}^{\mathrm{Ta}} \mathrm{Ta}_{2} \mathrm{O}_{5}$ and $\mathrm{Ta}(\mathrm{Zn}) \mathrm{O}$ deposited by HiPIMS showed lower intensity of the relative fluorescence with Syto 9 stain, and the $\mathrm{Ta}(\mathrm{Zn}) \mathrm{O}$ exhibited the lowest intensity in both of the S. aureus and A. actinomycetemcomitans bacterial colonies (Figure 6). The antibacterial capability of $\mathrm{ZnO}$ has been proved in previous studies [22-24]. The content ratio of $\mathrm{Zn}$ in the surface coating is a critical issue because the zinc-oxide not only has the ability of improving the antibacterial properties but also increases the cell cytotoxicity [40]. To maintain both of the characteristics of biocompatibility and antibacterial ability, it is important to control the content ratio and manufacture procedure of $\mathrm{ZnO}$-contained coatings. 

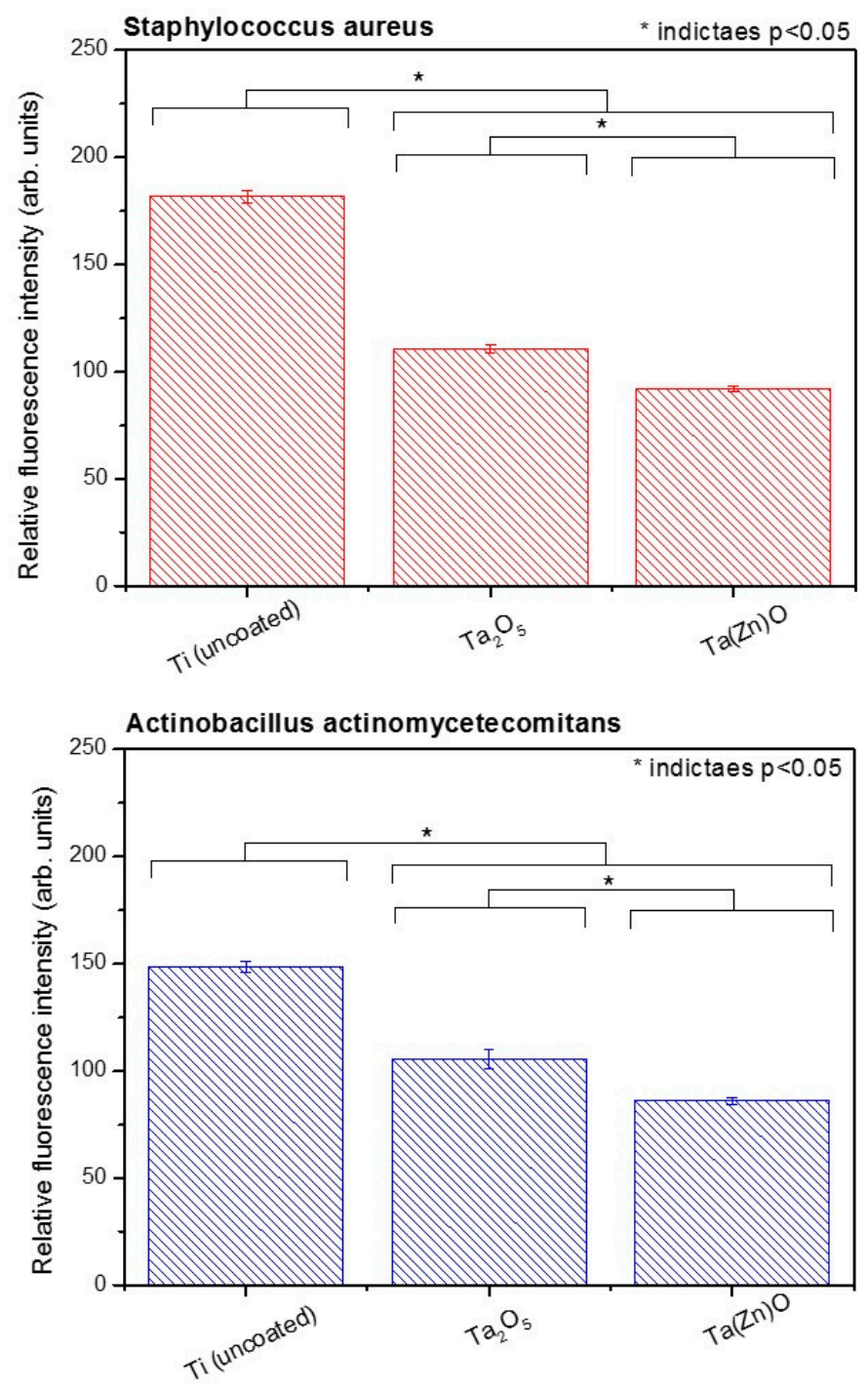

Figure 6. Antibacterial properties of each specimen against S. aureus and A. actinomycetemcomitans. The relative fluorescence intensity represents the bacterial residue with STYO 9 stain, and antibacterial properties among specimens against $S$. aureus and A. actinomycetemcomitans were different significantly $(p<0.05)$. Post-hoc pairwise comparisons were conducted by the Turkey test. The differences were considered significant when $p<0.05$.

\subsection{Biocompatibility Tests of Cytotoxicity and Cell Viability}

To compare the biocompatible characteristic of the specimens of the uncoated $\mathrm{Ti}, \mathrm{Ta}_{2} \mathrm{O}_{5}$, and $\mathrm{Ta}(\mathrm{Zn}) \mathrm{O}$ with the pretreatment of PEO in the soft tissue- and hard tissue-derived cells, the cytotoxicity and cell viability tests were individually performed with both HSF and MG-63 cells and quantified by MTT assay. Figure 7 showed the results of the cytotoxicity test of all specimens in HSF and MG-63 cells, and Figure 8 showed the results of the cell viability. In Figure 7, HSF cells were cultured with the conditioned medium collected from the untreated $\mathrm{Ti}_{1}, \mathrm{Ta}_{2} \mathrm{O}_{5}$, and $\mathrm{Ta}(\mathrm{Zn}) \mathrm{O}$ coatings. Based on the guideline of ISO 10993-5, the group of cells cultured with medium is recommended as the control group for the further comparison with cells cultured with the extraction from any kinds of materials. Besides, the group of the untreated Ti specimen was also essential in this study. Although Ti has been considered as a biomaterial with desirable biocompatibility and mechanical properties especially for the dental and orthopedic implants, coatings with $\mathrm{Ta}_{2} \mathrm{O}_{5}$ or $\mathrm{Ta}(\mathrm{Zn}) \mathrm{O}$ represented better cell viability and lower cytotoxicity in HSF cells in this study (Figure 7). No significant difference of 
the cytotoxicity was found between the specimens with $\mathrm{Ta}_{2} \mathrm{O}_{5}$ and $\mathrm{Ta}(\mathrm{Zn}) \mathrm{O}$ thin films. $\mathrm{ZnO}$ did not deteriorate the cytotoxicity of HSF cells on the $\mathrm{Ta}(\mathrm{Zn}) \mathrm{O}$ coated samples.
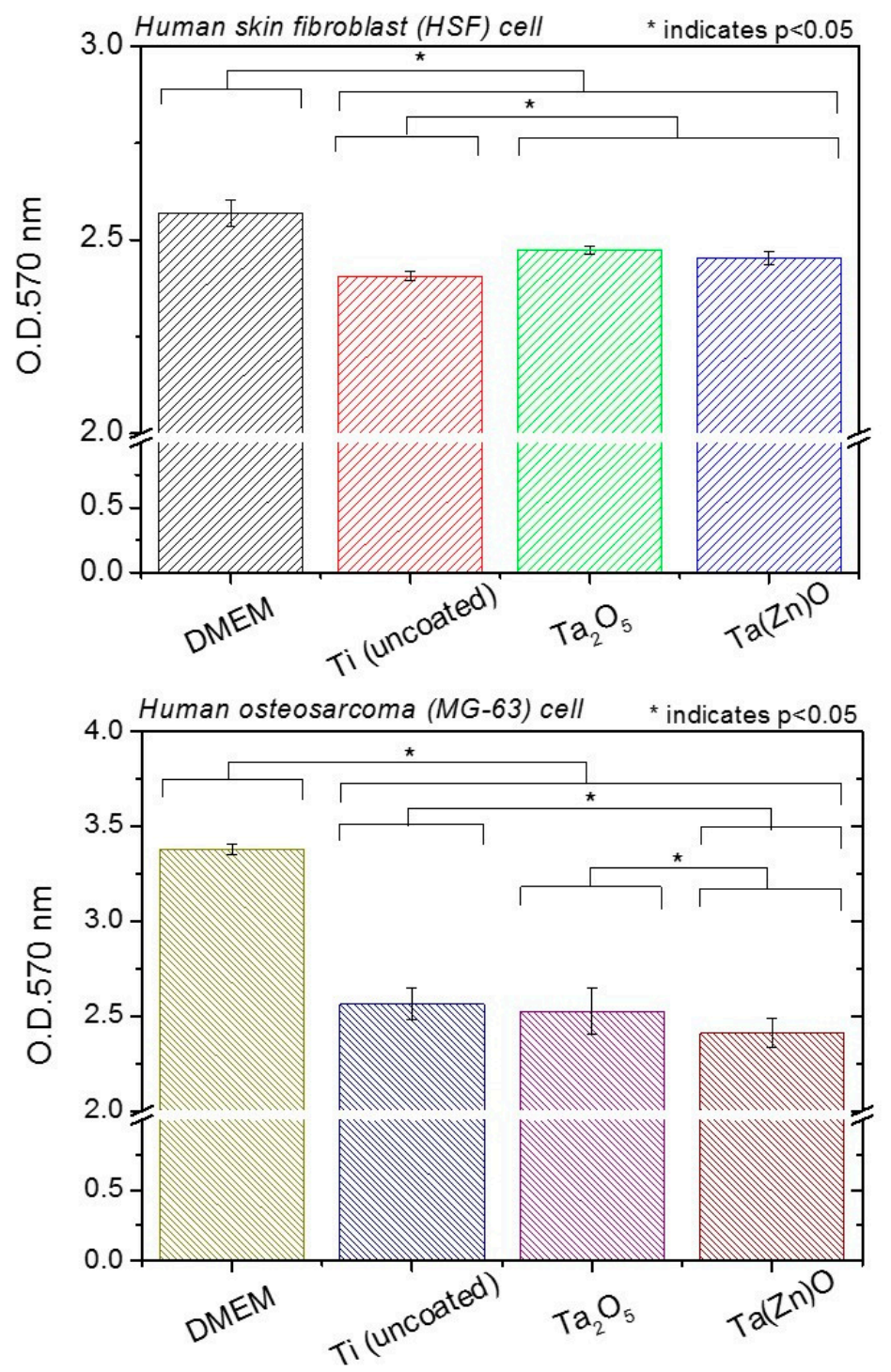

Figure 7. The cytotoxic effect of the uncoated $\mathrm{Ti}, \mathrm{Ta}_{2} \mathrm{O}_{5}$, and $\mathrm{Ta}(\mathrm{Zn}) \mathrm{O}$ films on HSF and MG-63 cells compared to the regular culture medium (DMEM) according to the ISO 10993-5 methodology. The mean vales of O.D. were different significantly among all samples $(p<0.05)$. Post-hoc pairwise comparisons were conducted by the Turkey test and the differences were considered significant when $p<0.05$.

In Figure 7, the optical density of MG-63 cells cultured with DMEM was much higher than the cells cocultured with the conditioned medium collected from each kind of specimen. No significant difference of the cytotoxicity was observed between $\mathrm{Ta}_{2} \mathrm{O}_{5}$ and the uncoated Ti specimens. $\mathrm{Ta}_{2} \mathrm{O}_{5}$ had similar cytotoxicity of MG-63 cells to the pure Ti. Coatings with $\mathrm{Ta}(\mathrm{Zn}) \mathrm{O}$ showed the lowest OD values compared to other groups, indicating that $\mathrm{Ta}(\mathrm{Zn}) \mathrm{O}$ thin films may induce higher level of the cytotoxicity in MG-63 cells. Clinical reports have been provided the evidence that the pure Ti is widely applied to the soft and hard tissues due to its favorable biocompatibility and mechanical properties, especially to the dental and orthopedic implants in clinic [41,42]. Recently, Ta bulk materials and $\mathrm{Ta}_{2} \mathrm{O}_{5}$ thin films have also been considered as a desirable biomaterial especially applying to clinical implants for the orthopedics and the dentistry [43-46]. Various clinical uses also provide reliable evidences that the addition of Ta of implants improves the hard-tissue growth and healing. Ta is desirable for the 
adhesion, migration, and proliferation of bone cells. The results above indicated that the deposition of $\mathrm{Ta}_{2} \mathrm{O}_{5}$ onto the PEO-pretreated Ti substrates with micro porous structure may provide higher affinity to the hard tissue-derived cells for cell growth.

To further study the potential biocompatibility of the uncoated $\mathrm{Ti}_{1} \mathrm{Ta}_{2} \mathrm{O}_{5}$, and $\mathrm{Ta}(\mathrm{Zn}) \mathrm{O}$ films, HSF and MG-63 cells were individually and directly cultured onto each kind of specimen for $48 \mathrm{~h}$ followed by MTT assay (Figure 8).
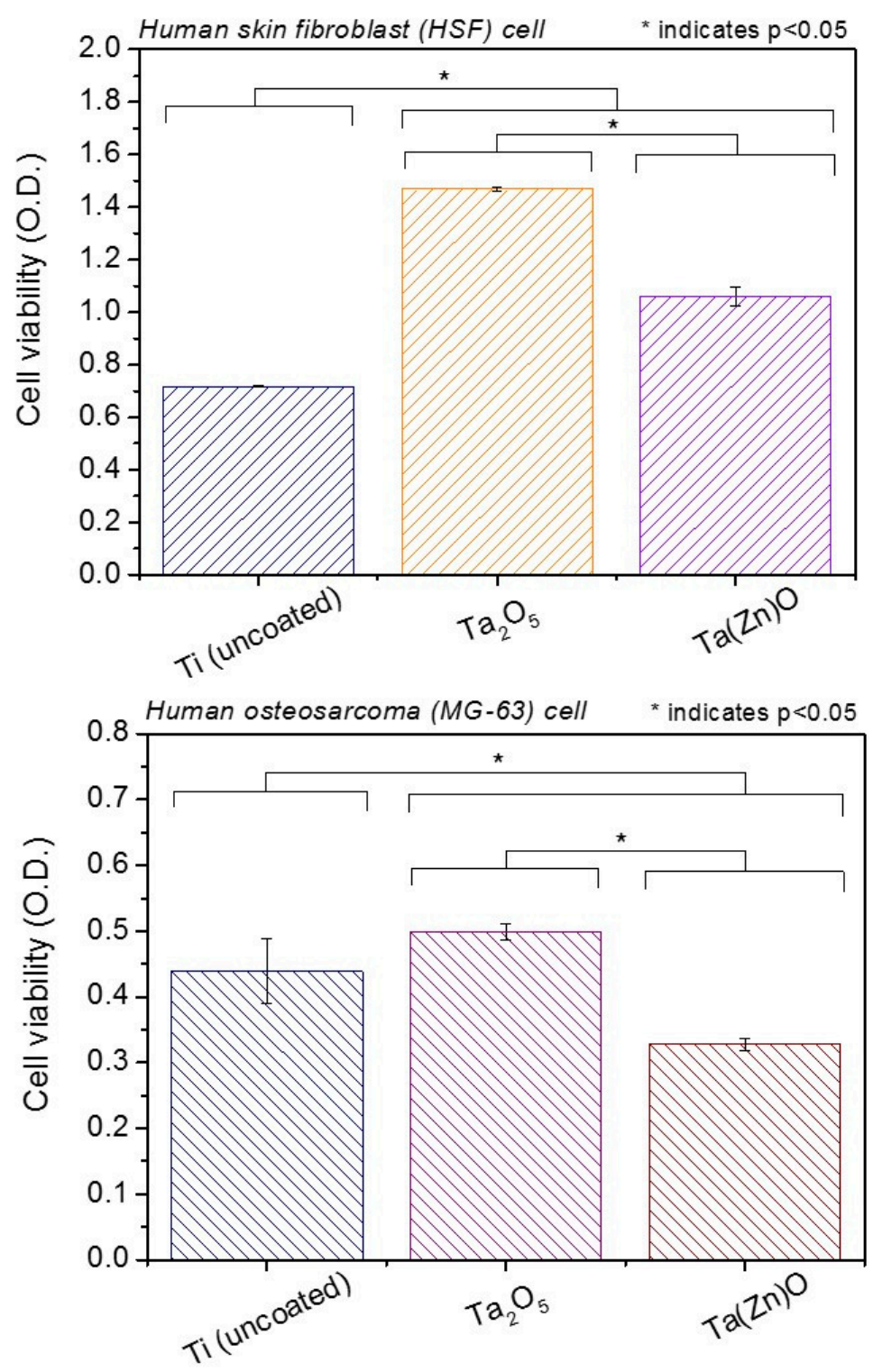

Figure 8. Cell viabilities of fibroblast cells and osteosarcoma cells on each sample. HSF and MG-63 cells were individually and directly cultured onto each kind of specimen for $48 \mathrm{~h}$ followed by MTT assay. The mean vales of O.D. were different significantly among all samples $(p<0.05)$. Post-hoc pairwise comparisons were conducted by the Turkey test and the differences were considered significant when $p<0.05$.

In HSF cells, the results showed that the cell viability of $\mathrm{Ta}_{2} \mathrm{O}_{5}$ films was not only the greatest compared to the other two kinds of specimens, but also was almost two-fold higher than the uncoated Ti specimen. The thin films with $\mathrm{Ta}(\mathrm{Zn}) \mathrm{O}$ even showed almost 1.5 -fold level of the cell viability compared to the uncoated Ti specimen. It indicated that the Ta-contained oxide thin films deposited onto the surface of $\mathrm{Ti}$ substrates may enhance the biocompatibility of HSF cells. It is known that 
cells perceive the surface landscape of Ti implants at very different scales ranging from the molecular level to nanoscale. Vaidulych et al. [47] had studied the convex and concave surface in the nano-scale range of $\mathrm{Ta}_{2} \mathrm{O}_{5}$ thin films for tailoring the osteoblast adhesion. The surface morphology affected the cell adhesion. Their results showed that primary human osteoblasts were found to sustain the viability on all kinds of these nano-scale convex and concave surfaces; however, $\mathrm{Ta}_{2} \mathrm{O}_{5}$ with the concave topography showed restrained adhesion of the cells. In this study, the biocompatible effect of $\mathrm{Ta}_{2} \mathrm{O}_{5}$ and $\mathrm{Ta}(\mathrm{Zn}) \mathrm{O}$ specimens with rough and porous structure in the range of micro-scale was obviously found in HSF cells. The biocompatible effect of $\mathrm{Ta}_{2} \mathrm{O}_{5}$ specimens in MG-63 cells was consistent with the findings observed in HSF cells. In MG-63 cells, the cell viability of $\mathrm{Ta}_{2} \mathrm{O}_{5}$ films was higher than the uncoated Ti specimen. Vannozzi, L. et al. [48] studied the $\mathrm{ZnO}$ effect on the cell adhesion and viability of composite thin films based on a blend of poly(ethylene glycol)-block-poly( $\varepsilon$-caprolactone) methyl ether (PEG-b-PCL) and poly(l-lactic acid), doped with $\mathrm{ZnO}$ nanoparticles. In-vitro tests were carried out with cells of the musculoskeletal apparatus (fibroblasts, osteoblasts, chondrocytes, and myoblasts). All cell types showed good adhesion and viability on the $\mathrm{ZnO}$-doped thin film samples. They found that a higher content of $\mathrm{ZnO}$ nanoparticles in the matrix demonstrated higher bioactivity. However, in this study, the coatings with $\mathrm{Ta}(\mathrm{Zn}) \mathrm{O}$ showed the lowest level of the cell viability in MG-63 cells, indicating that the content of $\mathrm{Zn}$ may repress the cell viability of MG-63 cells. Safety issues may arise in relation to a possible release of $\mathrm{ZnO}$ from the matrix. $\mathrm{Zn}$ ions dissociated from $\mathrm{ZnO}$ could be associated with cytotoxic phenomena to MG-63 cells. Toxicity was influenced by the $\mathrm{ZnO}$ concentration.

These findings above showed that the biological effects of each kind of specimens on the cytotoxicity or the cell viability in the soft tissue-derived cells (HSF cells) was not exactly as same as the results observed in the hard tissue-derived cells (MG-63 cells). For MG-63 cells, the osteoblast-like cells are critical to the surface composition and the microstructure of the materials. It has been proved that the biomaterial surface with the porous structures is better for the osteoblastic cell adhesion, migration, and proliferation [49]. However, the behavior of the fibroblast-like HSF cells is not easily affected by the surface roughness of the materials [50], and in a bacterial environment, the proper surface may give soft tissue-derived cells a better chance to compete with bacteria to cover on the surface of $\mathrm{Ti}$ implants [51,52]. This study shows that there is a close relationship between the amount and chemical composition of the thin films serving as a support of the cells.

\section{Conclusions}

In this study, PEO were mainly applied to form a well-distributed porous $\mathrm{TiO}_{2}$ surface, and HiPIMS was further adopted to deposit $\mathrm{Ta}_{2} \mathrm{O}_{5}$ and $\mathrm{Ta}(\mathrm{Zn}) \mathrm{O}$ coatings on the porous surface of Ti to discuss the material properties, antibacterial performance, and biocompatibility of the thin films.

The conclusions are shown as follows:

1) Scanning electron microscopy and 3D laser microscopy were used to observe the morphology of the specimens. The surfaces of the Ti specimens that had been subjected to PEO were fully covered with a $\mathrm{TiO}_{2}$ layer. Through the use of HiPIMS, the deposition of the $\mathrm{Ta}_{2} \mathrm{O}_{5}$ and $\mathrm{Ta}(\mathrm{Zn}) \mathrm{O}$ films would not affect the porous structure on the specimen surface. $\mathrm{The}^{\mathrm{Ta}} \mathrm{O}_{5}$ and $\mathrm{Ta}(\mathrm{Zn}) \mathrm{O}$-deposited Ti had high surface roughness and this surface roughening and porous structure may influence the biocompatibility. The results of water contact angle measurement demonstrated that the pure Ti substrate, $\mathrm{Ta}_{2} \mathrm{O}_{5}$, and $\mathrm{Ta}(\mathrm{Zn}) \mathrm{O}$ specimen had contact angles of $43.13 \pm 10.0^{\circ}, 3.3 \pm 0.36^{\circ}$, and $16.75 \pm 3.7^{\circ}$, respectively. The deposited $\mathrm{Ta}_{2} \mathrm{O}_{5}$ coating on the porous Ti was capable of enhancing surface wettability, and adding $\mathrm{Zn}$ to thin films increased surface hydrophobicity as compared to $\mathrm{Ta}_{2} \mathrm{O}_{5}$. The deposited $\mathrm{Ta}(\mathrm{Zn}) \mathrm{O}$ contained amorphous $\mathrm{Ta}_{2} \mathrm{O}_{5}$ and crystalline $\mathrm{ZnO}$. The development of the crystalline $\mathrm{ZnO}$ structure during growth is controlled by the HiPIMS deposition process.

2) Antibacterial properties against Gram-positive and Gram-negative bacteria were performed. Compared to the untreated $\mathrm{Ti}$, both specimens with $\mathrm{Ta}_{2} \mathrm{O}_{5}$ and $\mathrm{Ta}(\mathrm{Zn}) \mathrm{O}$ thin films showed lower intensity of the relative fluorescence with Syto 9 stain in both these two bacterial colonies, 
and they had improved antibacterial abilities against $S$. aureus and A. actinomycetemcomitans. The $\mathrm{Ta}(\mathrm{Zn}) \mathrm{O}$ deposited by HiPIMS exhibited the lowest intensity in both of the $S$. aureus and A. actinomycetemcomitans bacterial colonies, and it showed the best antibacterial performance.

3) The results of the ISO-10993-5 cell cytotoxicity and cell viability MTT assay tests revealed that the $\mathrm{Ta}_{2} \mathrm{O}_{5}$ or $\mathrm{Ta}(\mathrm{Zn}) \mathrm{O}$ coated $\mathrm{Ti}$ had better cell viability and lower cytotoxicity in HSF cells, and both coatings possessed high biocompatibilities in this study. The cell activity of $\mathrm{Ta}(\mathrm{Zn}) \mathrm{O}$ coated Ti decreased slightly when reacting to the MG63 cells. The result showed that the $\mathrm{Ta}_{2} \mathrm{O}_{5}$ coating on Ti surface with porous structure improved adhesion, migration, and proliferation for the osteoblastic cell. Due to the different properties of cells, HSF and MG-63 cells represented different behaviors of cell cytoxicity and cell viability in each kind of coating specimens on Ti.

Author Contributions: Conceptualization: Y.-Y.C., H.-L.H.; methodology: Y.-Y.C., H.-L.H.; validation: Y.-Y.C.; formal analysis: Y.-Y.C., H.-L.H., M.-T.T.; investigation: Y.-Y.C.; resources: Y.-Y.C.; data Ccration: Y.-Y.C., H.-L.H.; writing-original draft preparation: Y.-Y.C., Y.-J.L.; writing-review and editing: Y.-Y.C., H.-L.H., M.-T.T.; visualization: J.-T.H.; supervision: Y.-Y.C.; project administration: Y.-Y.C., H.-L.H.; funding acquisition: Y.-Y.C., J.-T.H. All authors have read and agreed to the published version of the manuscript.

Funding: This research was supported by the Ministry of Science and Technology (MOST 107-2218-E-131 -001 and MOST 108-2221-E-150-020-MY3) of Taiwan. This work was also financially supported by the "High Entropy Materials Center" from The Featured Areas Research Center Program within the framework of the Higher Education Sprout Project by the Ministry of Education (MOE) and from the Project MOST 108-3017-F-007-002- by Ministry of Science and Technology (MOST) in Taiwan.

Acknowledgments: The instrumental assistance from the Common Lab. for Micro/Nano Sci. and Tech. of National Formosa University is sincerely appreciated.

Conflicts of Interest: The authors declare no conflict of interest.

\section{References}

1. Xiao, M.; Chen, Y.; Biao, M.; Zhang, X.; Yang, B. Bio-functionalization of biomedical metals. Mater. Sci. Eng. C 2017, 70, 1057-1070. [CrossRef] [PubMed]

2. Chen, Q.; Thouas, G.A. Metallic implant biomaterials. Mater. Sci. Eng. R 2015, 87, 1-57. [CrossRef]

3. Devgan, S.; Sidhu, S.S. Evolution of surface modification trends in bone related biomaterials: A review. Mater. Chem. Phys. 2019, 233, 68-78. [CrossRef]

4. Chouirfa, H.; Bouloussa, H.; Migonney, V.; Falentin-Daudré, C. Review of titanium surface modification techniques and coatings for antibacterial applications. Acta Biomater. 2019, 83, 37-54. [CrossRef]

5. Villafuerte, K.R.V.; Martinez, C.D.J.H.; Dantas, F.T.; Carrara, H.H.A.; dos Reis, F.J.C.; Palioto, D.B. The impact of chemotherapeutic treatment on the oral microbiota of patients with cancer: A systematic review. Oral Surg. Oral Med. Oral Pathol. Oral Radiol. 2018, 125, 552-566. [CrossRef]

6. Mortazavi, G.; Jiang, J.; Meletis, E.I. Investigation of the plasma electrolytic oxidation mechanism of titanium. Appl. Surf. Sci. 2019, 488, 370-382. [CrossRef]

7. Tanase, C.E.; Golozar, M.; Best, S.M.; Brooks, R.A. Cell response to plasma electrolytic oxidation surface-modified low-modulus $\beta$-type titanium alloys. Colloids Surf. B 2019, 176, 176-184. [CrossRef]

8. Janson, O.; Gururaj, S.; Pujari-Palmer, S.; Karlsson Ott, M.; Strømme, M.; Engqvist, H.; Welch, K. Titanium surface modification to enhance antibacterial and bioactive properties while retaining biocompatibility. Mater. Sci. Eng. C 2019, 96, 272-279. [CrossRef]

9. Tsai, M.-T.; Chang, Y.-Y.; Huang, H.-L.; Hsu, J.-T.; Chen, Y.-C.; Wu, A.Y.-J. Characterization and antibacterial performance of bioactive Ti-Zn-O coatings deposited on titanium implants. Thin Solid Films 2013, 528, 143-150. [CrossRef]

10. Wang, Q.; Qiao, Y.; Cheng, M.; Jiang, G.; He, G.; Chen, Y.; Zhang, X.; Liu, X. Tantalum implanted entangled porous titanium promotes surface osseointegration and bone ingrowth. Sci. Rep. 2016, 6, 26248. [CrossRef]

11. Li, Y.; Zhao, T.; Wei, S.; Xiang, Y.; Chen, H. Effect of Ta2O5/TiO2 thin film on mechanical properties, corrosion and cell behavior of the NiTi alloy implanted with tantalum. Mater. Sci. Eng. C 2010, 30, 1227-1235. [CrossRef]

12. Levine, B.R.; Sporer, S.; Poggie, R.A.; Della Valle, C.J.; Jacobs, J.J. Experimental and clinical performance of porous tantalum in orthopedic surgery. Biomaterials 2006, 27, 4671-4681. [CrossRef] [PubMed] 
13. Hanzlik, J.A.; Day, J.S.; Contributors, A.; Group, I.R.S. Bone ingrowth in well-fixed retrieved porous tantalum implants. J. Arthroplast. 2013, 28, 922-927. [CrossRef] [PubMed]

14. Issack, P.S. Use of porous tantalum for acetabular reconstruction in revision hip arthroplasty. JBJS 2013, 95, 1981-1987. [CrossRef]

15. Bencharit, S.; Byrd, W.C.; Altarawneh, S.; Hosseini, B.; Leong, A.; Reside, G.; Morelli, T.; Offenbacher, S. Development and applications of porous tantalum trabecular metal-enhanced titanium dental implants. Clin. Implant Dent. Relat. Res. 2014, 16, 817-826. [CrossRef]

16. Chang, Y.-Y.; Huang, H.-L.; Chen, H.-J.; Lai, C.-H.; Wen, C.-Y. Antibacterial properties and cytocompatibility of tantalum oxide coatings. Surf. Coat. Technol. 2014, 259, 193-198. [CrossRef]

17. Mareci, D.; Chelariu, R.; Gordin, D.-M.; Ungureanu, G.; Gloriant, T. Comparative corrosion study of Ti-Ta alloys for dental applications. Acta Biomater. 2009, 5, 3625-3639. [CrossRef]

18. Zhang, Y.; Nayak, T.R.; Hong, H.; Cai, W. Biomedical applications of zinc oxide nanomaterials. Curr. Mol. Med. 2013, 13, 1633-1645. [CrossRef]

19. Seo, H.-J.; Cho, Y.-E.; Kim, T.; Shin, H.-I.; Kwun, I.-S. Zinc may increase bone formation through stimulating cell proliferation, alkaline phosphatase activity and collagen synthesis in osteoblastic MC3T3-E1 cells. Nutr. Res. Pract. 2010, 4, 356-361. [CrossRef]

20. Yamaguchi, M.; Yamaguchi, R. Action of zinc on bone metabolism in rats: Increases in alkaline phosphatase activity and DNA content. Biochem. Pharmacol. 1986, 35, 773-777. [CrossRef]

21. Jin, G.; Cao, H.; Qiao, Y.; Meng, F.; Zhu, H.; Liu, X. Osteogenic activity and antibacterial effect of zinc ion implanted titanium. Colloids Surf. B 2014, 117, 158-165. [CrossRef] [PubMed]

22. Raghupathi, K.R.; Koodali, R.T.; Manna, A.C. Size-dependent bacterial growth inhibition and mechanism of antibacterial activity of zinc oxide nanoparticles. Langmuir 2011, 27, 4020-4028. [CrossRef] [PubMed]

23. Qi, K.; Cheng, B.; Yu, J.; Ho, W. Review on the improvement of the photocatalytic and antibacterial activities of ZnO. J. Alloys Compd. 2017, 727, 792-820. [CrossRef]

24. Banoee, M.; Seif, S.; Nazari, Z.E.; Jafari-Fesharaki, P.; Shahverdi, H.R.; Moballegh, A.; Moghaddam, K.M.; Shahverdi, A.R. ZnO nanoparticles enhanced antibacterial activity of ciprofloxacin against Staphylococcus aureus and Escherichia coli. J. Biomed. Mater. Res. Part B 2010, 93, 557-561. [CrossRef] [PubMed]

25. Zhang, X.; Wu, H.; Geng, Z.; Huang, X.; Hang, R.; Ma, Y.; Yao, X.; Tang, B. Microstructure and cytotoxicity evaluation of duplex-treated silver-containing antibacterial TiO2 coatings. Mater. Sci. Eng. C 2014, 45, 402-410. [CrossRef]

26. Huang, H.-L.; Tsai, M.-T.; Lin, Y.-J.; Chang, Y.-Y. Antibacterial and biological characteristics of tantalum oxide coated titanium pretreated by plasma electrolytic oxidation. Thin Solid Films 2019, 688, 137268. [CrossRef]

27. Greczynski, G.; Zhirkov, I.; Petrov, I.; Greene, J.E.; Rosen, J. Control of the metal/gas ion ratio incident at the substrate plane during high-power impulse magnetron sputtering of transition metals in Ar. Thin Solid Films 2017, 642, 36-40. [CrossRef]

28. Alias, R.; Mahmoodian, R.; Genasan, K.; Vellasamy, K.M.; Hamdi Abd Shukor, M.; Kamarul, T. Mechanical, antibacterial, and biocompatibility mechanism of PVD grown silver-tantalum-oxide-based nanostructured thin film on stainless steel 316L for surgical applications. Mater. Sci. Eng. C 2020, 107, 110304. [CrossRef]

29. Rack, P.D.; Potter, M.D.; Woodard, A.; Kurinec, S. Negative ion resputtering in Ta2Zn3O8 thin films. J. Vac. Sci. Technol. A 1999, 17, 2805-2810. [CrossRef]

30. Kim, G.; Hong, L.Y.; Jung, J.; Kim, D.-P.; Kim, H.; Kim, I.J.; Kim, J.R.; Ree, M. The biocompatability of mesoporous inorganic-organic hybrid resin films with ionic and hydrophilic characteristics. Biomaterials 2010, 31, 2517-2525. [CrossRef]

31. Petrov, I.; Barna, P.B.; Hultman, L.; Greene, J.E. Microstructural evolution during film growth. J. Vac. Sci. Technol. A 2003, 21, S117-S128. [CrossRef]

32. Mirica, E.; Kowach, G.; Du, H. Modified Structure Zone Model to Describe the Morphological Evolution of ZnO Thin Films Deposited by Reactive Sputtering. Cryst. Growth Des. 2004, 4, 157-159. [CrossRef]

33. Mozetic, M.; Vesel, A.; Primc, G.; Eisenmenger-Sittner, C.; Bauer, J.; Eder, A.; Schmid, G.H.S.; Ruzic, D.N.; Ahmed, Z.; Barker, D.; et al. Recent developments in surface science and engineering, thin films, nanoscience, biomaterials, plasma science, and vacuum technology. Thin Solid Films 2018, 660, 120-160. [CrossRef]

34. Sul, Y.-T. The significance of the surface properties of oxidized titanium to the bone response: Special emphasis on potential biochemical bonding of oxidized titanium implant. Biomaterials 2003, 24, 3893-3907. [CrossRef] 
35. Chennakesavulu, K.; Reddy, M.M.; Reddy, G.R.; Rabel, A.M.; Brijitta, J.; Vinita, V.; Sasipraba, T.; Sreeramulu, J. Synthesis, characterization and photo catalytic studies of the composites by tantalum oxide and zinc oxide nanorods. J. Mol. Struct. 2015, 1091, 49-56. [CrossRef]

36. Li, J.; Dai, W.; Wu, G.; Guan, N.; Li, L. Fabrication of Ta2O5 films on tantalum substrate for efficient photocatalysis. Catal. Commun. 2015, 65, 24-29. [CrossRef]

37. NuLi, Y.-N.; Fu, Z.-W.; Chu, Y.-Q.; Qin, Q.-Z. Electrochemical and electrochromic characteristics of Ta2O5-ZnO composite films. Solid State Ionics 2003, 160, 197-207. [CrossRef]

38. Rezek, J.; Novák, P.; Houška, J.; Pajdarová, A.D.; Kozák, T. High-rate reactive high-power impulse magnetron sputtering of transparent conductive Al-doped $\mathrm{ZnO}$ thin films prepared at ambient temperature. Thin Solid Films 2019, 679, 35-41. [CrossRef]

39. Reed, A.N.; Shamberger, P.J.; Hu, J.J.; Muratore, C.; Bultman, J.E.; Voevodin, A.A. Microstructure of ZnO thin films deposited by high power impulse magnetron sputtering. Thin Solid Films 2015, 579, 30-37. [CrossRef]

40. Chang, Y.-Y.; Lai, C.-H.; Hsu, J.-T.; Tang, C.-H.; Liao, W.-C.; Huang, H.-L. Antibacterial properties and human gingival fibroblast cell compatibility of $\mathrm{TiO} 2 / \mathrm{Ag}$ compound coatings and $\mathrm{ZnO}$ films on titanium-based material. Clin. Oral Investig. 2012, 16, 95-100. [CrossRef]

41. Geetha, M.; Singh, A.; Asokamani, R.; Gogia, A. Ti based biomaterials, the ultimate choice for orthopaedic implants-A review. Prog. Mater. Sci. 2009, 54,397-425. [CrossRef]

42. Sidambe, A. Biocompatibility of advanced manufactured titanium implants-A review. Materials 2014, 7, 8168-8188. [CrossRef] [PubMed]

43. Meng, F.; Li, Z.; Liu, X. Synthesis of tantalum thin films on titanium by plasma immersion ion implantation and deposition. Surf. Coat. Technol. 2013, 229, 205-209. [CrossRef]

44. Mei, S.; Yang, L.; Pan, Y.; Wang, D.; Wang, X.; Tang, T.; Wei, J. Influences of tantalum pentoxide and surface coarsening on surface roughness, hydrophilicity, surface energy, protein adsorption and cell responses to PEEK based biocomposite. Colloids Surf. B 2019, 174, 207-215. [CrossRef]

45. Sagherian, B.H.; Claridge, R.J. The Use of Tantalum Metal in Foot and Ankle Surgery. Orthop. Clin. N. Am. 2019, 50, 119-129. [CrossRef]

46. De Paolis, M.; Zucchini, R.; Romagnoli, C.; Romantini, M.; Mariotti, F.; Donati, D.M. Middle term results of tantalum acetabular cups in total hip arthroplasty following pelvic irradiation. Acta Orthop. Traumatol. Turc. 2019, 53, 165-169. [CrossRef]

47. Vaidulych, M.; Pleskunov, P.; Kratochvíl, J.; Mašková, H.; Kočová, P.; Nikitin, D.; Hanuša, J.; Kyliána, K.; Štěrbabc, J.; Biederman, H.; et al. Convex vs concave surface nano-curvature of $\mathrm{Ta}_{2} \mathrm{O}_{5}$ thin films for tailoring the osteoblast adhesion. Surf. Coat. Technol. 2020, 393, 125805-125812. [CrossRef]

48. Vannozzi, L.; Gouveia, P.J.; Pingue, P.; Canale, C.; Ricotti, L. Novel ultra-thin films based on a blend of PEG-b-PCL and PLLA and doped with ZnO nanoparticles. ACS Appl. Mater. Interfaces 2020, 12, 21398-21410. [CrossRef]

49. Martin, J.; Schwartz, Z.; Hummert, T.; Schraub, D.; Simpson, J.; Lankford, J., Jr.; Dean, D.D.; Cochran, D.L.; Boyan, B. Effect of titanium surface roughness on proliferation, differentiation, and protein synthesis of human osteoblast-like cells (MG63). J. Biomed. Mater. Res. 1995, 29, 389-401. [CrossRef]

50. Richards, R. The effect of surface roughness on fibroblast adhesion in vitro. Injury 1996, 27, S/C38-S/C43. [CrossRef]

51. Zhao, B.; Van Der Mei, H.C.; Subbiahdoss, G.; de Vries, J.; Rustema-Abbing, M.; Kuijer, R.; Busscher, H.J.; Ren, Y. Soft tissue integration versus early biofilm formation on different dental implant materials. Dent. Mater. 2014, 30, 716-727. [CrossRef] [PubMed]

52. Wytrwal, M.; Koczurkiewicz, P.; Zrubek, K.; Niemiec, W.; Michalik, M.; Kozik, B.; Szneler, E.; Bernasik, A.; Madeja, Z.; Nowakowska, M.; et al. Growth and motility of human skin fibroblasts on multilayer strong polyelectrolyte films. J. Colloid Interface Sci. 2016, 461, 305-316. [CrossRef] [PubMed]

(C) 2020 by the authors. Licensee MDPI, Basel, Switzerland. This article is an open access article distributed under the terms and conditions of the Creative Commons Attribution (CC BY) license (http://creativecommons.org/licenses/by/4.0/). 